University of Nebraska - Lincoln

DigitalCommons@University of Nebraska - Lincoln

\title{
Effect of Temperature on Cs+ Sorption and Desorption in Subsurface Sediments at the Hanford Site, U.S.A.
}

Chongxuan Liu

Pacific Northwest National Laboratory, chongxuan.liu@pnl.gov

John M. Zachara

Pacific Northwest National Laboratory, john.zachara@pnl.gov

Odeta Qafoku

Pacific Northwest National Laboratory

Steve Smith

Pacific Northwest National Laboratory

Follow this and additional works at: https://digitalcommons.unl.edu/usdoepub

Part of the Bioresource and Agricultural Engineering Commons

Liu, Chongxuan; Zachara, John M.; Qafoku, Odeta; and Smith, Steve, "Effect of Temperature on Cs+ Sorption and Desorption in Subsurface Sediments at the Hanford Site, U.S.A." (2003). US Department of Energy Publications. 222.

https://digitalcommons.unl.edu/usdoepub/222

This Article is brought to you for free and open access by the U.S. Department of Energy at DigitalCommons@University of Nebraska - Lincoln. It has been accepted for inclusion in US Department of Energy Publications by an authorized administrator of DigitalCommons@University of Nebraska - Lincoln. 


\section{Effect of Temperature on $\mathrm{Cs}^{+}$ Sorption and Desorption in Subsurface Sediments at the Hanford Site, U.S.A.}

CHONGXUAN LIU, * JOHN M. ZACHARA, ODETA QAFOKU, AND STEVE C. SMITH

Pacific Northwest National Laboratory,

Richland, Washington 99352

The effects of temperature on $\mathrm{Cs}^{+}$sorption and desorption were investigated in subsurface sediments from the U.S. Department of Energy Hanford Site. The site has been contaminated at several locations by the accidental leakage of high-level nuclear waste (HLW) containing ${ }^{137} \mathrm{Cs}^{+}$. The high temperature of the self-boiling, leaked HLW fluid and the continuous decay of various radionuclides carried by the waste supernatant have resulted in elevated vadose temperatures (currently up to $72{ }^{\circ} \mathrm{C}$ ) below the Hanford S-SX tank farm that have dissipated slowly from the time of leakage (1970). The effect of temperature on $\mathrm{Cs}^{+}$ sorption was evaluated through batch binary $\mathrm{Cs}^{+}-\mathrm{Na}^{+}$ exchange experiments on pristine sediments, while $\mathrm{Cs}^{+}$ desorption was studied in column experiments using ${ }^{137} \mathrm{Cs}^{+}$. contaminated sediments. $\mathrm{Cs}^{+}$adsorption generally decreased with increasing temperature, with a more apparent decrease at low aqueous $\mathrm{Cs}^{+}$concentration $\left(10^{-10}\right.$ $\left.10^{-6} \mathrm{~mol} / \mathrm{L}\right) . \mathrm{Cs}^{+}$desorption from the contaminated sediments increased with increasing temperature. The results indicated that the free energy of $\mathrm{Na}^{+}-\mathrm{Cs}^{+}$exchange on the Hanford sediment had a significant enthalpy component that was estimated to be $-17.87( \pm 2.01)$ and $-4.82( \pm 0.44) \mathrm{kJ} / \mathrm{mol}\left(\right.$ at $\left.298^{\circ} \mathrm{C}\right)$ for the high- and low-affinity exchange sites, respectively. Both $\mathrm{Cs}^{+}$adsorption and desorption at elevated temperature could be well simulated by a two-site ion exchange model, with the conditional exchange constants corrected by the exchange enthalpy effect. The effect of temperature on $\mathrm{Cs}^{+}$desorption kinetics was also evaluated using a stop-flow technique. The kinetics of desorption of the exchangeable pool (which was less than the total adsorbed concentration) were found to be rapid under the conditions studied.

\section{Introduction}

High-level nuclear waste (HLW) resulted from the reprocessing of irradiated uranium fuel for Pu extraction. Within the United States, millions of gallons of HLW remain in storage at U.S. Department of Energy facilities awaiting safe, long-term stabilization and disposal. The HLW are enriched in fission products including ${ }^{137} \mathrm{Cs}^{+},{ }^{90} \mathrm{Sr}^{2+}$, and many other radionuclides. Some of the HLW wereself-boiling for several years after reprocessing as a result of the decay of short half-

* Correspondingauthor phone: (509)376-0129; fax: (509)376-3650; e-mail: chongxuan.liu@pnl.gov. Corresponding address: Pacific Northwest National Laboratory, P.O. Box 999, MSIN K8-96, Richland, WA 99352. life radionuclides. HLW has been accidentally released to the vadose zone at Hanford and other DOE sites as a result of tank overfilling, transfer line breakage, and tank failures. ${ }^{137} \mathrm{Cs}^{+}$is one of several contaminants of concern in these leak events. In this communication we evaluate the effects of temperature on $\mathrm{Cs}^{+}$adsorption and desorption from Hanford sediments. The research provides insights on the sorption chemistry of ${ }^{137} \mathrm{Cs}^{+}$in a HLW vadose zone plume at Hanford's S-SX tank farm that contains in excess of 1000 $\mathrm{kCi}$ of ${ }^{137} \mathrm{Cs}^{+}$. Subsurface temperatures within this plume have remained in excess of $50^{\circ} \mathrm{C}$ for over 30 years since the time of HLW leakage as a result of radioactive decay and the high thermal load of the self-boiling HLW. Figure 1 shows current vertical profiles of ${ }^{137} \mathrm{Cs}^{+}$and temperature proximate to tank SX-108.

Cesium strongly and preferentially adsorbs on 2:1 layer silicate minerals in soils and sediments (1-3). Cesium sorption on micaceous minerals such as illite $(4,5)$ and sediments containing such minerals $(3,6)$ has typically been treated as a cation exchange process involving two or more sites with distinctive exchange energies (high and low affinity). The high-affinity sites are believed to reside along the weathered edges or collapsed interlayer regions of micaceous minerals, while the low-affinity sites populate the basal and interlamellar regions of both nonexpansible and expansible phyllosilicates (e.g., vermiculites and smectites). The high affinity of $\mathrm{Cs}^{+}$for fixed charge sites on micaceous minerals results from the unique registry of the dehydrated $\mathrm{Cs}^{+}$ion with the ditrigonal siloxane cavity on high charge density phyllosilicates $(7,8)$.

The effects of temperature on $\mathrm{Cs}^{+}$adsorption and desorption are not well established. Komarneni and Roy (9) found that hydrothermal treatment $\left(200-400^{\circ} \mathrm{C}\right.$ at 300 bar) of shale or sediments containing vermiculite or illite decreased both $\mathrm{Cs}^{+}$adsorption and desorption. X-ray diffraction examination of the sediments indicated that the decrease in $\mathrm{Cs}^{+}$adsorption and desorption resulted from the collapse of edge-interlayer sites. This collapse reduced the number of sites available for adsorption and locked adsorbed $\mathrm{Cs}^{+}$within the structure, preventing desorption. Secondary $\mathrm{Cs}^{+}$containing minerals (i.e., $\mathrm{CSAISi}_{2} \mathrm{O}_{6}$ ) resulting from hydrothermal treatment were also speculated to retard $\mathrm{Cs}^{+}$ desorption in some cases $(10,11)$.

We report here on the influence of temperature on $\mathrm{Cs}^{+}$ adsorption to and desorption from Hanford sediment over the temperature range of $15-65^{\circ} \mathrm{C}$. Adsorption isotherms were measured in batch mode for $\mathrm{Na}^{+}-\mathrm{Cs}^{+}$ion exchangeon pristine Hanford sediments at variable temperature to characterize the temperature dependence of the adsorption process. Desorption experiments wereperformed usingsmall columns packed with contaminated sediments containing $10^{8} \mathrm{pCi} / \mathrm{g}^{137} \mathrm{Cs}^{+}$collected from beneath leaked Hanford tank SX-108. Thesediment was contaminated by release of caustic, self-boiling HLW in 1970. The columns were leached with $\mathrm{NaNO}_{3}$ (the primary electrolyte present in Hanford HLW) at various temperatures to evaluate the temperature dependence of desorption. A two-site ion exchange model that was developed and applied previously to sediments from this site $(3,6,12)$ was used to interpret the results.

\section{Materials and Methods}

Sediment Collection and Analysis. Pristine core samples were collected from four monitoring wells surrounding the S-SX tank farm (3). The subsamples of the field-moist materials were air-dried to a constant weight and sieved to pass a 2-mm mesh. Gravels $>2 \mathrm{~mm}$ were removed from the 

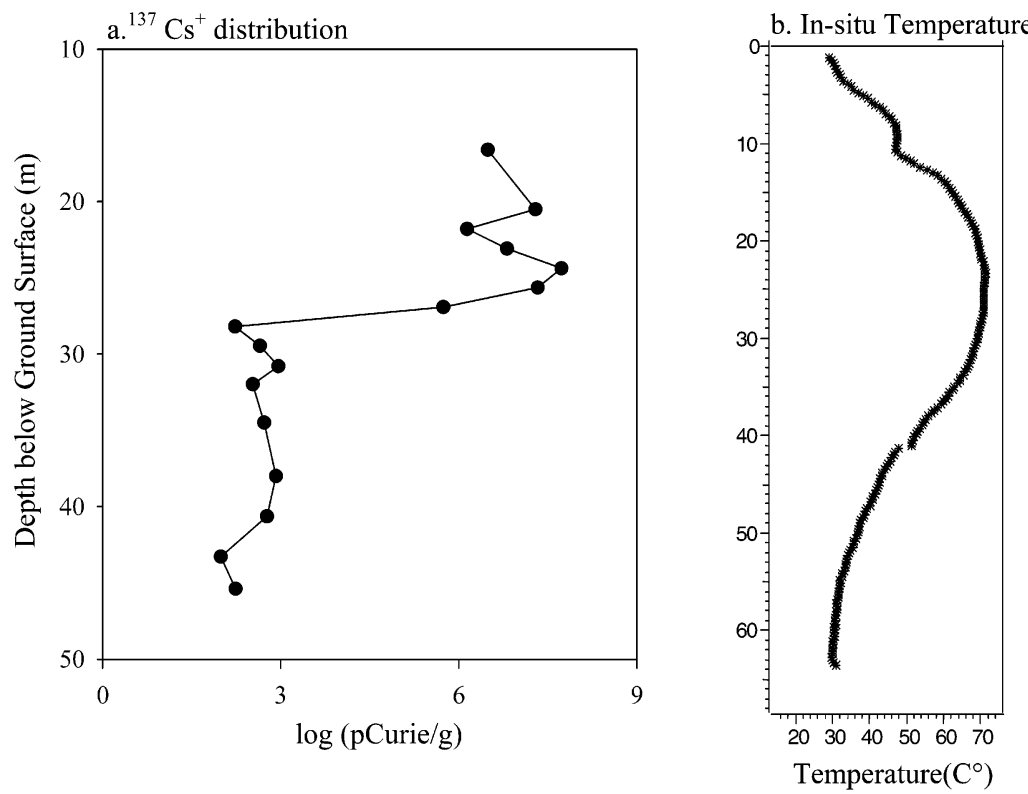

FIGURE 1. Vertical distribution of temperature and ${ }^{137} \mathrm{CS}^{+}$beneath tank SX-108 in the S-SX tank farm at the Hanford Site. The contaminated sample used in this study was from depth of $25.8 \mathrm{~m}$ below ground surface.

air-dried materials during the sieving process. The sieved materials were mixed thoroughly to obtain a homogeneous sample and were designated as the Above B composite. The cation exchange capacity (CEC) of the compositeranged from 4.26 to $8.25 \times 10^{-5}$ equiv/g of dry soil as determined previously using different methods (3), and a value of $8.25 \times 10^{-5}$ equiv/ $\mathrm{g}$ was consistent with all previous experimental and modeling results of $\mathrm{Cs}^{+}$sorption and desorption at room temperature $(3,6)$.

The ${ }^{137} \mathrm{Cs}^{+}$-contaminated sediments were collected from BoreholeSX-108 (aboreholenear tankSX-108) in theHanford S-SX tank farm at a sample location approximately $25.8 \mathrm{~m}$ below ground surface. The sample collection and analyses are described elsewhere (13). Thesubsamples wereair-dried, sieved, and mixed following the same procedures used for the pristine sediments. Sediments both with and without $\mathrm{Cs}^{+}$contamination had thesamemineral composition, except that certain mineral phases in the contaminated sediments were altered by reaction with alkaline HLW (12).

The mineralogy of the Hanford pristine sediment was described previously (3). Briefly, it consisted predominantly of quartz with lesser amounts of plagioclase and potassium feldspars, mica, chlorite, and smectite for particles larger than $2 \mu \mathrm{m}$. The clay fraction ( $<2 \mu \mathrm{m})$ consisted of smectite, chlorite, and mica. X-ray diffraction showed the micas to be muscovite, biotite, and vermiculitized biotite.

$\mathrm{Cs}^{+}$Sorption to NaOAc-Treated above B Sediment. The Above B sediment was treated with sodium acetate ( $\mathrm{NaOAc}$ ) at $\mathrm{pH} 4.5$ to dissolve solublesalts and cal cite, and to saturate the exchanger phase with $\mathrm{Na}^{+}$. The detail experimental procedure for this treatment was described elsewhere (3). Cesium sorption on the treated Above $B$ sediment was measured at three temperatures $-30,45$, and $65^{\circ} \mathrm{C}$-in 0.1 $\mathrm{mol} / \mathrm{L} \mathrm{NaNO}_{3}$ electrolyte. Previous exchange measurements (3) had been performed at $30^{\circ} \mathrm{C}$. The sorption experiments used a solid concentration of about $10 \mathrm{~g} / \mathrm{L}$ and $\mathrm{Cs}^{+}$ concentrations in the range of $10^{-1}-10^{-9} \mathrm{~mol} / \mathrm{L}$ in $\mathrm{CsNO}_{3}$ labeled with 7 to $20 \times 10^{3} \mathrm{dpm} / \mathrm{mL}^{137} \mathrm{Cs}^{+}$. The background $\mathrm{Cs}^{+}$in sediment suspensions of $0.1 \mathrm{~mol} / \mathrm{L} \mathrm{NaNO}_{3}$ solution was below detection limit $(1.1 \mu \mathrm{g} / \mathrm{L})$ and was less than $1 . \times$ $10^{-9} \mathrm{~mol} / \mathrm{L}$ estimated from the measurements of $\mathrm{Cs}^{+}$in 5 $\mathrm{mol} / \mathrm{L} \mathrm{NaNO}$ solution $\left(5.9 \mu \mathrm{g} / \mathrm{L}\right.$ or $\left.4.4 \times 10^{-8} \mathrm{~mol} / \mathrm{L}\right)$ and dilution trend from $5 \mathrm{~mol} / \mathrm{L}$ to $1 \mathrm{~mol} / \mathrm{L} \mathrm{NaNO}_{3}$ solutions. The suspensionswere shaken in a $30-\mathrm{mL}$ polycarbonatetube at $40 \mathrm{rpm}$ for $16 \mathrm{~h}$. After equilibration, the suspensions were centrifuged, and the supernatants were measured for ${ }^{137} \mathrm{Cs}^{+}$. The ${ }^{137} \mathrm{Cs}^{+}$activity of the sample was counted for $30 \mathrm{~min}$ using a Wallac Model 1480 gamma counter with an $80-\mathrm{mm}$ Nal crystal detector. The count window was set at 560-710 $\mathrm{keV}$, yielding a count efficiency of 0.207. The sorbed $\mathrm{Cs}^{+}$was calculated from the difference between the initial and final aqueous concentrations of $\mathrm{Cs}^{+}$.

Leaching of $\mathrm{Cs}^{+}$from the Contaminated Sediments. Approximately $2 \mathrm{~g}$ of air-dried sediments were packed into polypropylene columns $3.1 \mathrm{~cm}$ long $\times 0.78 \mathrm{~cm}$ in diameter. The columns were connected to a peristaltic pump on one side and a fraction collector on the other. Each column was inserted into a water jacket at a specific temperature. Immediately before the columnswere connected to a leaching solution, approximately $10 \mathrm{~mL}$ of pure $\mathrm{CO}_{2}$ gas was injected through the columns to displace air from the sediment pore space. A uniform movement of the leaching solution through the packed air-dried sediments was observed. Sediment leachates were collected every $6 \mathrm{~min}$, and the mass of collected solutions was determined to val idate the flow rate. After all the leachates were collected, the packed columns wereflushed with deionized water and weighed; the sediment pore space was determined as a weight difference between wet and air-dried sediment. The ratio of dry solid weight to aqueous volume was $3.03 \times 10^{3} \mathrm{~g} / \mathrm{L}$ in the packed column, a valuecorresponding to 0.47 porosity under an assumption of solid density of $2.65 \mathrm{~kg} / \mathrm{L}$. The concentration of ${ }^{137} \mathrm{Cs}^{+}$in the leachates was measured as described above for $\mathrm{Cs}^{+}$ sorption.

In one set of column desorption experiments, the sediments were leached continuously with $0.5 \mathrm{~mol} / \mathrm{L} \mathrm{NaNO}_{3}$ for about 10 pore volumes at $15^{\circ} \mathrm{C}$ and a flow rate of $0.1 \mathrm{~mL} /$ $\mathrm{min}$. This flow rate yielded a residence time of $6 \mathrm{~min}$. The temperature of the water jacket then was increased to $55^{\circ} \mathrm{C}$, and the sediments were leached continuously for another 10 pore volumes. At this time, a stop-flow method was applied for $2.5 \mathrm{~h}$, followed by another 10 pore volumes of leaching before the temperature of the water jacket decreased to 35 ${ }^{\circ} \mathrm{C}$. After leaching for about 10 pore volumes at $35^{\circ} \mathrm{C}$, the stop-flow method was applied again for $2.5 \mathrm{~h}$, followed by continued leaching for about eight pore volumes before the temperature decreased to $15^{\circ} \mathrm{C}$. Similarly, the leaching at 15 ${ }^{\circ} \mathrm{C}$ was stopped for $2.5 \mathrm{~h}$ after 8 pore volumes and resumed 

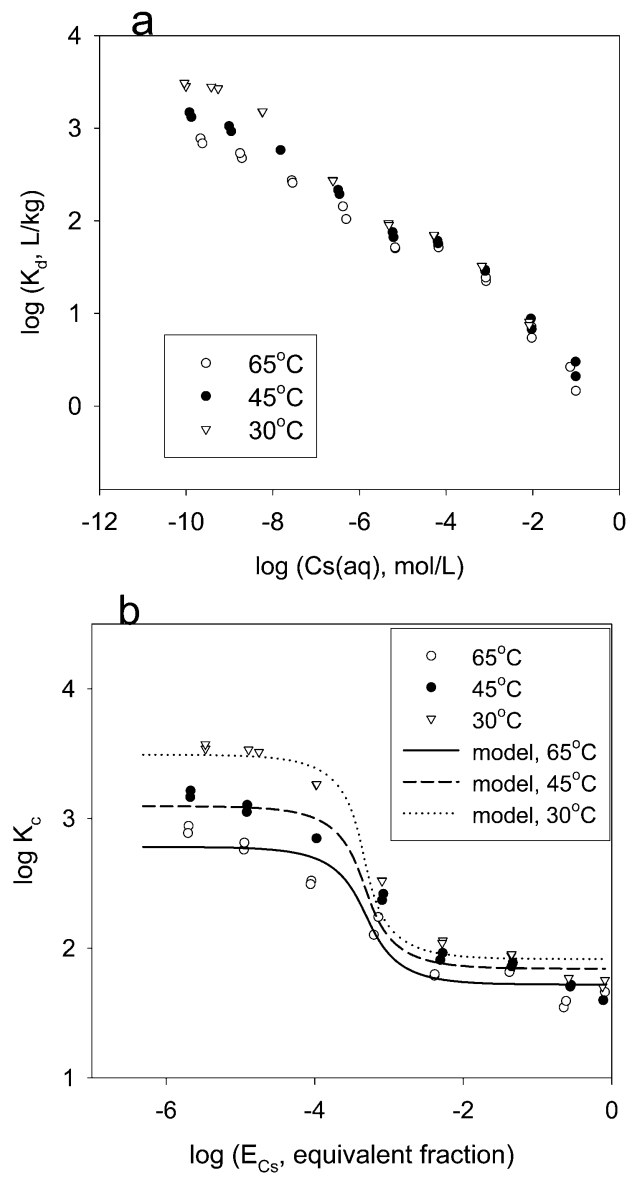

FIGURE 2. $\mathrm{Cs}^{+}$sorption in $0.1 \mathrm{~mol} / \mathrm{L} \mathrm{NaNO}_{3}$ electrolyte on the $\mathrm{NaOAC}$ treated pristine Hanford sediment: (a) $\mathrm{Cs}^{+}$distribution coefficient $\left(K_{d}\right)$ as a function of temperature and equilibrium aqueous $\mathbf{C s}^{+}$ concentration; (b) experimental and modeling results of conditional exchange constant $\left(K_{c}\right)$ as a function of temperature and equivalent $\mathrm{Cs}^{+}$fraction $\left(E_{\mathrm{CS}}\right)$ on the solid phase.

for another eight pore volumes beforetermination. Theother set of leaching experiments involved increasing the temperature from $15^{\circ}$ to $35^{\circ} \mathrm{C}$ and then to $55^{\circ} \mathrm{C}$ in the water jacket. At the midpoint of the leaching process at each temperature, the flow wasstopped for $2.5 \mathrm{~h}$ and then resumed as described above.

\section{Results and Discussion}

Effect of Temperature on $\mathbf{C s}^{+}$Sorption. Cesium sorption, as measured by the concentration distribution ratio $\left(K_{d}\right)$, increased with decreasing temperature at low-equilibrium aqueous $\mathrm{Cs}^{+}$concentration ( $10^{-10}-10^{-5} \mathrm{~mol} / \mathrm{L}$ ) (Figure $2 \mathrm{a}$ ). The measured $K_{d}$ values nearly doubled at low concentration as temperature decreased from $45^{\circ}$ to $30^{\circ} \mathrm{C}$ and increased about five times from $65^{\circ}$ to $30^{\circ} \mathrm{C}$. However, the $K_{d}$ changes with temperature became smaller with increasing aqueous $\mathrm{Cs}^{+}$concentrations ( $>10^{-5} \mathrm{~mol} / \mathrm{L}$ ). These results indicated that temperature mainly affected $\mathrm{Cs}^{+}$sorption behavior in the high $\mathrm{K}_{d}$ region.

The conditional $\mathrm{Cs}^{+}$exchange coefficients $\left(\mathrm{K}_{c}\right)$ at different temperatures (Figure 2b) exhibited multisite exchange behavior, as observed previously at room temperature for pure illite (4) and sediments containing micaceous and smectitesorbents (3). The exchange reaction may be written as

$$
\mathrm{Cs}_{(\mathrm{aq})}^{+}+\mathrm{NaX}=\mathrm{CsX}+\mathrm{Na}^{+}{ }_{(\mathrm{aq})}
$$

TABLE 1. Parameters Estimated from $\mathrm{Cs}^{+}$Sorption Results at Variable Temperatures ${ }^{\mathrm{a}}$

\begin{tabular}{|c|c|c|c|c|c|c|}
\hline \multirow{2}{*}{$\begin{array}{c}T \\
\left({ }^{\circ} \mathrm{C}\right)\end{array}$} & \multicolumn{2}{|c|}{$\begin{array}{c}\log K_{c} \\
\left(\mathrm{Cs}^{+} \text {for } \mathrm{Na}^{+}\right)\end{array}$} & \multicolumn{2}{|c|}{$\underset{(\mathrm{kJ} / \mathrm{mol})}{\Delta H^{\circ}}$} & \multicolumn{2}{|c|}{$\underset{(\mathrm{J} / \mathrm{mol} \mathrm{K})}{\Delta S^{\circ}}$} \\
\hline & site I & site II & site I & site II & site I & site II \\
\hline $\begin{array}{l}30 \\
45 \\
65\end{array}$ & $\begin{array}{l}6.827(0.066) \\
6.417(0.071) \\
6.088(0.062)\end{array}$ & $\begin{array}{l}1.916(0.050) \\
1.842(0.055) \\
1.719(0.047)\end{array}$ & $\begin{array}{r}-17.87 \\
(2.01)\end{array}$ & $\begin{array}{l}-4.82 \\
(0.44)\end{array}$ & $\begin{array}{c}-2.41 \\
(6.49)\end{array}$ & $\begin{array}{c}0.08 \\
(1.41)\end{array}$ \\
\hline
\end{tabular}

where $\mathrm{NaX}$ and CsX are the exchanger phase species of $\mathrm{Na}^{+}$ and $\mathrm{Cs}^{+}$and $\mathrm{Cs}^{+}{ }_{(\mathrm{aq})}$ and $\mathrm{Na}^{+}{ }_{(\mathrm{aq})}$ are aqueous species. The conditional exchange constant $\left(K_{c}\right)$ was defined as

$$
\mathrm{K}_{\mathrm{c}}=\left(\mathrm{N}_{\mathrm{Cs}} / \mathrm{N}_{\mathrm{Na}}\right)\left(\left[\mathrm{Na}_{(\mathrm{aq})}^{+}\right] /\left[\mathrm{Cs}_{(\mathrm{aq})}^{+}\right]\right)
$$

where $\mathrm{N}_{\mathrm{Cs}}$ and $\mathrm{N}_{\mathrm{Na}}$ are the mole fractions on the exchanger phase, and $\left[\mathrm{Cs}^{+}{ }_{(\mathrm{aq})}\right]$ and $\left[\mathrm{Na}^{+}{ }_{(\mathrm{aq})}\right]$ are the aqueous concentrations for species $\mathrm{Cs}^{+}$and $\mathrm{Na}^{+}$, respectively.

The $K_{c}$ generally decreased with increasing temperature, with more apparent decreases in the high-affinity (high- $\mathrm{K}_{\mathrm{c}}$ ) region (Figure 2b). At each temperature, the $K_{c}$ sharply decreased at an equivalent fraction $\left[\mathrm{E}_{\mathrm{Cs}}=\mathrm{Cs}^{+}(\right.$equiv/g)/ CEC(equiv/g)] of $5 \times 10^{-4}$. The inflection point of $K_{c}$ was an indication of the saturation of the high-affinity exchange site. This inflection point has been used to estimate the capacity of that site (4). The observance of a common inflection point at each different temperature indicated that the equivalent fraction of the high-affinity site did not change with temperature. This result was in contrast with a previous observation (9) that the capacity of the high-affinity site sharply decreased with increasing temperature due to the collapse of the edge-interlayer region. The mild temperature change $\left(30-65^{\circ} \mathrm{C}\right.$ ) and low pressure (1 atm) of this study may explain such a difference.

Because of the step characteristic of the experimental $\mathrm{K}_{c}$ values at each temperature (Figure $2 \mathrm{~b}$ ), a two-site exchange model (3) was applied here to describe the $\mathrm{Cs}^{+}$sorption

$K_{c}\left(E_{C s}\right)=\left(b+\sqrt{b^{2}+4 K_{c}^{\prime} K_{c}^{\prime \prime} E_{C s}\left(1-E_{C s}\right)}\right) /\left(2-2 E_{C s}\right)$

where $b=\left(E^{\prime}-E_{C s}\right) K_{c}^{\prime}+\left(1-E^{\prime}-E_{C S}\right) K_{c}^{\prime \prime} ; K_{c}^{\prime}$ and $K_{c}^{\prime \prime}$ are the conditional exchange coefficients for site I and II, respectively; $E^{l}$ is thefraction of the sediment CEC contributed by sitel; and $\mathrm{E}_{\mathrm{Cs}}$ is the equivalent fraction of total sorbed $\mathrm{Cs}^{+}$ among CEC. Thetwo-siteexchangemodel could bewell fitted to each $\mathrm{Cs}^{+}$sorption isotherm (Figure $2 \mathrm{~b}$ ) by adjusting the conditional exchange coefficients of the two sites. The highaffinity site fraction (E') was fixed at $4.5 \times 10^{-5}$ for all temperatures, which was consistent with the observed inflection point of the $K_{c}$ curves (Figure $2 b$ ). This same value of $E^{\prime}$ has been used to successfully describe other experimental results with variable ionic strength and exchanging electrolytes for this sediment (6). With a fixed capacity of high-affinity sites $\left(E^{\prime}\right)$, the change of the overall $K_{c}$ at each temperature was attributed to the changes in the conditional exchange constants (eq 3) for both the high and low affinity $\mathrm{Cs}^{+}$exchange sites (Table 1 ).

The effects of temperature on the exchange constant $\left(K_{e x}\right)$ may be described by the Gibbs-Helmholtz equation

$$
\frac{\partial \ln K_{e x}}{\partial(1 / T)}=-\frac{\Delta H}{R}
$$

where $\Delta \mathrm{H}$ is theenthalpy changefor reaction 1 at temperature $T$ and $R$ is the gas constant. The $K_{e x}$ is a function of the conditional exchangeconstant (eq 2) corrected by the activity 


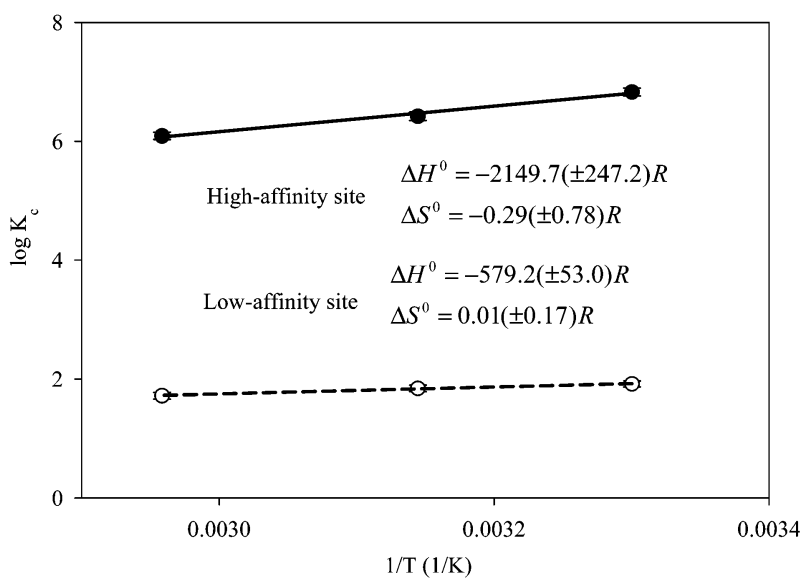

FIGURE 3. The relationship of the conditional exchange constants $\left(K_{c}\right)$ of $\mathrm{Cs}^{+}$for $\mathrm{Na}^{+}$at the high and low affinity sites to inverse temperature.

coefficients of aqueous and exchanger phase species. The ion exchange of $\mathrm{Cs}^{+}$on Hanford sediments at room temperature was found to be nonideal and influenced by the water activity (6). However, the activity coefficient ratios for the aqueous and exchanger phase species canceled one another for homovalent exchange (e.g., $\mathrm{Na}^{+}-\mathrm{Cs}^{+}$). As a result, the $\mathrm{K}_{\mathrm{c}}$ measured at different ionic strengths converged to a single line within the errors of experimental measurement in $0.1-5.0 \mathrm{~mol} / \mathrm{L} \mathrm{NaNO}_{3}$ (3). Because of this observation and the unavailability of temperature-variable ion-ion interaction parameters for the aqueous species pairs such as $\mathrm{Cs}^{+-}$ $\mathrm{Na}^{+}$and $\mathrm{Cs}^{+}-\mathrm{NO}_{3}{ }^{-}$, it was assumed in the following analysis that the activity coefficient ratios canceled one another at different temperatures so that $K_{\text {ex }}$ in eq 4 could be replaced by $\mathrm{K}_{\mathrm{c}}$.

$\mathrm{K}_{\mathrm{c}}$ (Table 1) showed a linear trend with $1 / \mathrm{T}$ for both the high and low affinity exchange sites (Figure 3). The linear relationship allowed us to approximate $\Delta \mathrm{H}$ as a constant and to integrate eq 4 to obtain

$$
\ln K_{c}=-\frac{\Delta H^{\circ}}{R T}+\frac{\Delta S^{\circ}}{R}
$$

where $\Delta \mathrm{H}^{\circ}$ and $\Delta \mathrm{S}^{\circ}$ are the standard enthalpy and entropy changes for reaction 1 , respectively. After linearly fitting eq 5 to the results of $\mathrm{K}_{\mathrm{c}}$ vs $1 / \mathrm{T}$ (Figure 3 ), we obtained $\Delta \mathrm{H}^{\circ}=$ $-17.87( \pm 2.01) \mathrm{kJ} / \mathrm{mol}$ for the high-affinity site and -4.82 $( \pm 0.44) \mathrm{kJ} / \mathrm{mol}$ for the low-affinity site (the values in bracket are standard deviations calculated from the variances of parameter estimates by linear regression). The estimated intercepts (or entropy changes $\Delta S^{\circ}$, for theexchangereaction, eq 5) were small for both sites, and the estimated values were associated with large uncertainties (Table 1 and Figure 3).

Effect of Temperature on $\mathrm{Cs}^{+}$Desorption from the Contaminated Hanford Sediment. The concentration of $\mathrm{CS}^{+}$ in the column effluent from the contaminated sediment increased with increasing temperature (Figures 4 and 5), indicating that $\mathrm{Cs}^{+}$desorption increased with temperature. Each column displayed an initial high release of $\mathrm{Cs}^{+}$in the first two pore volumes (Figures 4 and 5), before the data converged on "step function" behavior. Theinitial pulse was caused by residual $\mathrm{NaNO}_{3}$ (present as solid salt in the dried sediment) that dissolved in the $0.5 \mathrm{~mol} / \mathrm{L} \mathrm{NaNO}_{3}$ leaching solution and increased its concentration. This increased $\mathrm{Na}$ concentration proportionally enhanced $\mathrm{Cs}^{+}$desorption. The residual $\mathrm{NaNO}_{3}$ was completely dissolved in the first two pore volumes of leaching and after that point $\mathrm{Na}$ concentrations were constant and equal to those in the influent solutions $(0.5 \mathrm{~mol} / \mathrm{L})$. Thetotal $\mathrm{Cs}^{+}$concentrations in Figures

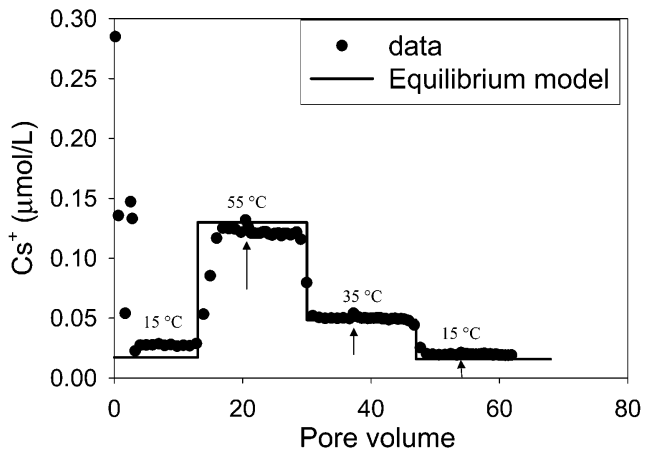

FIGURE 4. Effluent concentrations of $\mathrm{Cs}^{+}$from columns of contaminated Hanford sediment leached with $0.5 \mathrm{~mol} / \mathrm{L} \mathrm{NaNO}_{3}$ at different temperatures as noted. Solid lines are model calculations. The stop-flow event (labeled by arrow ) appears as a small increase in $\mathrm{Cs}^{+}$concentration midway through each temperature cycle.

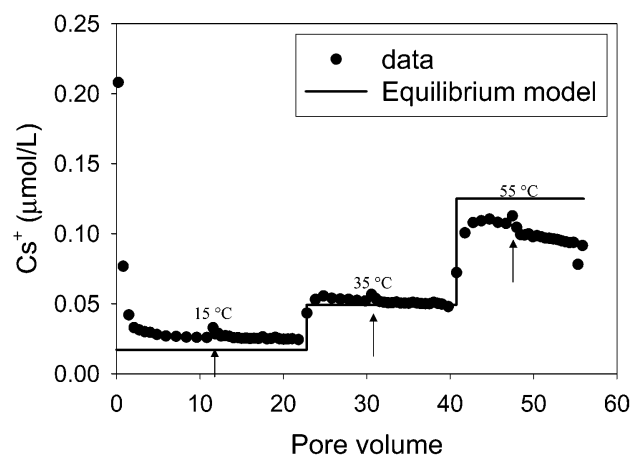

FIGURE 5. Effluent concentrations of $\mathrm{Cs}^{+}$from columns of contaminated Hanford sediment leached with $0.5 \mathrm{~mol} / \mathrm{L} \mathrm{NaNO}_{3}$ at different temperatures as noted. Solid lines are model calculations. The stop-flow event (labeled by arrow) appears as a small increase in $\mathrm{Cs}^{+}$concentration midway through each temperature cycle.

4 and 5 were calculated from the measured concentrations of ${ }^{137} \mathrm{Cs}^{+}$using the following relationship to account for the contribution from other $\mathrm{Cs}^{+}$isotopes including 133 and 135 (12):

$$
\mathrm{Cs}^{+}(\mathrm{mol} / \mathrm{L})=4.748{ }^{137} \mathrm{Cs}^{+}(\mathrm{mol} / \mathrm{L})
$$

The molar concentration is related to the activity of ${ }^{137} \mathrm{Cs}^{+}$ by

$$
\begin{aligned}
& { }^{137} \mathrm{Cs}^{+}(\mathrm{mol} / \mathrm{L})= \\
& { }^{137} \mathrm{Cs}^{+}(\mathrm{dpm} / \mathrm{L}) * 365.25 * 24 * 60 * \mathrm{t}_{1 / 2} /\left(\ln 2 * \mathrm{~N}_{\mathrm{A}}\right)
\end{aligned}
$$

where $t_{1 / 2}$ is the half-life of ${ }^{137} \mathrm{Cs}^{+}$decay (30.07 years), and $\mathrm{N}_{\mathrm{A}}$ is the Avogadro constant.

The $\mathrm{Cs}^{+}$breakthrough concentrations were generally constant at each temperature, except for the initial 1-2 pore volumes, indicating that the desorption rate was more rapid than the advective flux rate. The effluent concentration of $\mathrm{Cs}^{+}$increased slightly after $2.5 \mathrm{~h}$ of stop-flow at each temperature, but the concentrations rapidly returned to those measured prior to thestop-flow event. Theseresultsindicated that mass transfer effects on $\mathrm{Cs}^{+}$desorption were not significant at the advective flow rate used and within the experimental duration of 60 pore volumes.

There was a slight decrease in $\mathrm{Cs}^{+}$effluent concentration with time at $55^{\circ} \mathrm{C}$ (Figure 4) and a more obvious decrease at $55^{\circ} \mathrm{C}$ during the last stage of leaching (Figure 5). The cumulative mass outflow in the desorption experiments was calculated to be $7 \%$ (Figure 4) and 6\% (Figure 5) of total $\mathrm{Cs}^{+}$ associated with the sediment $\left[2.372 \times 10^{-8} \mathrm{~mol} / \mathrm{g}(12)\right]$. This quantity was less than the amount of exchangeable $\mathrm{Cs}^{+}$ 
measured for these same sediments in batch experiments (12) $\left(30-45 \%\right.$ of total $\left.\mathrm{Cs}^{+}\right)$. The exchangeable fraction included equilibrium and kinetically desorbablepools of $\mathrm{Cs}^{+}$ within the sediment (12). These results indicated that large extent of $\mathrm{Cs}^{+}$desorption at $55^{\circ} \mathrm{C}$ may have depleted the sorbed, equilibrium-exchangeableCs ${ }^{+}$concentration to levels where the kinetically controlled, desorbable fraction of $\mathrm{Cs}^{+}$ on the sediment became important. The rates of $\mathrm{Cs}^{+}$flux out of the column were $2.5,5.0$, and $11 \times 10^{-12} \mathrm{~mol} / \mathrm{min}$ at 15 , 35 , and $55^{\circ} \mathrm{C}$, respectively.

Increased $\mathrm{Cs}^{+}$desorption at higher temperature was consistent with the batch adsorption results observed using uncontaminated sediments (Figure 2). The decrease in the magnitude of the conditional exchange constants with increasing temperature allowed more mass action displacement of $\mathrm{Cs}^{+}$by $\mathrm{Na}^{+}$from the exchanger phase. This result, however, was again in contrast with the previous findings that $\mathrm{Cs}^{+}$desorption from sediments containing illite and vermiculite was decreased by high-temperature $\left(>200^{\circ} \mathrm{C}\right)$ treatment $(9,11)$. The decrease in desorption with increasing temperature was attributed to the edge-interlayer collapse $(9,11)$ and the formation of secondary $\mathrm{Cs}^{+}$-containing alumino-silicate minerals at high temperature $(10,11)$. The results of this study, however, clearly indicated that edgeinterlayer collapseand secondary mineral precipitation were not important relativeto the enthalpy effect in our moderate temperature range $\left(15-55^{\circ} \mathrm{C}\right)$. The finding that temperature more strongly affects $\mathrm{Cs}^{+}$ion exchange on the high-affinity site(Figure 2) may explain why there were no apparent effects of temperature on $\mathrm{Cs}^{+}$sorption and desorption in montmorillonite (14) where only low affinity $\mathrm{Cs}^{+}$ion exchange sites are likely to exist.

The desorption results (Figures 4 and 5) were well simulated by the two-site equilibrium exchange model that was parametrized by ion exchangemeasurements on pristine sediment (Figure $2 \mathrm{~b}$ ). The relationship in eq 5 was used to estimate the conditional exchange constants as a function of temperature. It was also assumed that $64 \%$ of $\mathrm{Cs}^{+}$sorbed on the sediment was exchangeable. The CEC of $7.49 \times 10^{-5}$ equiv/g of soil and the high-affinity site fraction of $5.7 \times 10^{-4}$ determined previously (12) for this sediment were used in the simulation. Soluble $\mathrm{Na}^{+}$and $\mathrm{K}^{+}$salts from $\mathrm{HLW}$ existed in the sediment (12), but these were not included in the simulation. As a result, the extent of $\mathrm{Cs}^{+}$desorption at the initiation of the experiment was under (not well)-simulated (Figures 4 and 5). The need to limit the desorbable fraction to $64 \%$ of thetotal sorbed $\mathrm{Cs}^{+}$concentration was an important part of the simulation. Comprehensive desorption studies of $\mathrm{Cs}^{+}$from these contaminated sediments have clearly shown that only a fraction of the absorbed pool is desorbable (12). Incomplete desorbability has been attributed to three major factors (12): collapse of the edge-interlayer region induced by the sorption of $\mathrm{Cs}^{+}$and/or $\mathrm{K}^{+}$, armoring or blocking of $\mathrm{Cs}^{+}$sorption sites by the secondary alumino-silicates precipitated concurrently with or after $\mathrm{Cs}^{+}$adsorption, and slow diffusion of $\mathrm{Cs}^{+}$within interlayer regions.

Implication to $\mathrm{Cs}^{+}$Retardation and Migration in Field. This study has shown that temperature, through an exchange enthalpy effect on the high affinity site, can significantly influence the adsorption and desorption of $\mathrm{Cs}^{+}$within the in-ground $\mathrm{Cs}^{+}$pool (Figure 1). Increasing temperature makes theion exchange reaction between sorbed $\mathrm{Na}^{+}$and aqueous $\mathrm{Cs}^{+}$less favorable. Accordingly, the retardation of $\mathrm{Cs}^{+}$by ion exchange is decreased, and its mobility is increased. $K_{d}$ based calculations of the SX-108 ${ }^{137} \mathrm{Cs}^{+}$plume have al ways underestimated $\mathrm{Cs}^{+}$mobility, and various explanations have been advanced including colloid migration. The enhancement of radionuclide mobility by colloids including organic or inorganic particles in subsurface environments has been documented (15-17). The transport calculations have been
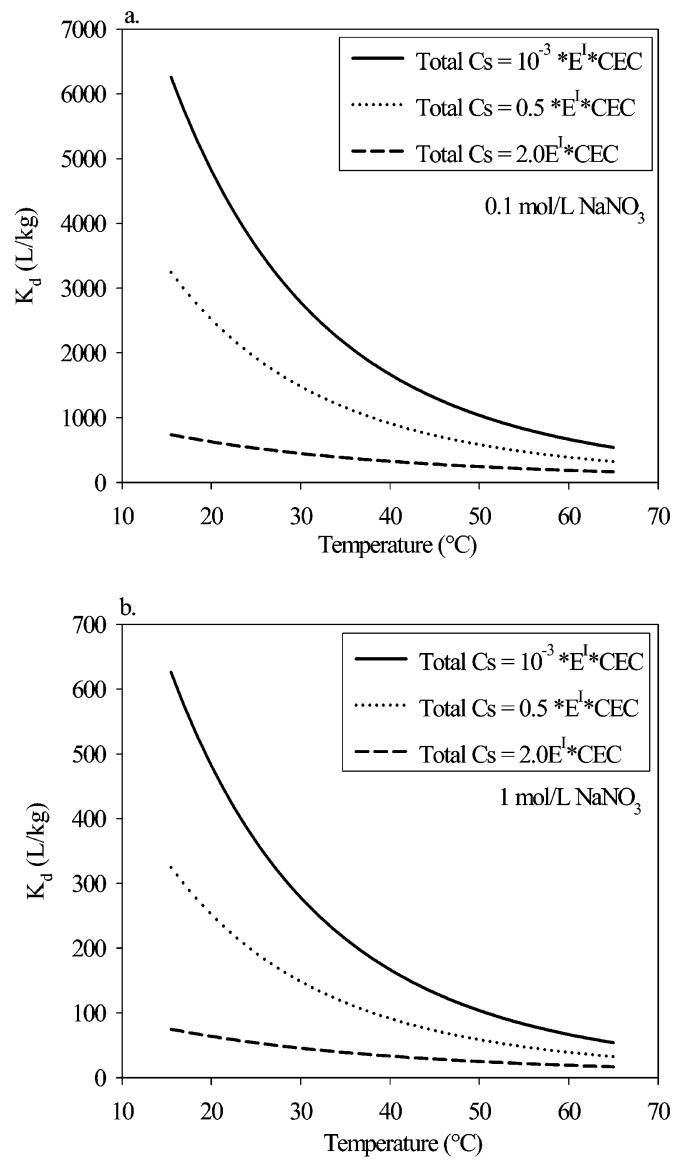

FIGURE 6. Simulation of the $C s^{+}$distribution coefficient $\left(K_{d}\right)$ as a function of temperature and $\mathrm{Cs}^{+}$adsorption density. [A porosity of 0.47 , high-affinity site fraction (E') of $5.7 \times 10^{-4}$, and sediment CEC of 7.49 mequiv/ $100 \mathrm{~g}$ corresponding to those in the leaching columns in Figures 4 and 5 were used in the simulation.] (a) and (b) show $K_{\mathrm{d}}$ in 0.1 and $1 \mathrm{~mol} / \mathrm{L} \mathrm{NaNO}_{3}$ electrolytes, respectively.

based on sorption/ion exchange measurements (e.g., $K_{d}$ ) performed at room temperature. New results presented herein indicatethat $\mathrm{Cs}^{+}$retardation at the $73^{\circ} \mathrm{C}$ temperature observed in the core of the HLW plume would be well below that observed at $25^{\circ} \mathrm{C}$, all other conditions being equal. An interesting consequence of the temperature effects noted here is that the in-ground retardation of ${ }^{137} \mathrm{Cs}^{+}$will increase in the futureas the temperature of the vadosezonedecreases through heat dissipation. This phenomenon will further contribute to the in-situ immobilization of ${ }^{137} \mathrm{Cs}^{+}$.

The temperature effect was caused by the large enthal py change of the exchange reaction at the high-affinity sitewhere $\mathrm{Cs}^{+}$was sorbed preferentially. Because of the low concentration of the high-affinity site in Hanford sediment (e.g., 4 $\times 10^{-8}$ equiv/g) the effect of temperature on the $\mathrm{Cs}^{+}$ distribution coefficient $\left(K_{d}\right)$ is dependent on adsorption density, as shown by numerical simulation (Figure 6). The effect of the ionic strength on the selectivity coefficients was neglected in the simulation. The $K_{d}$ decreases with increasing temperature when the adsorption density is below the capacity of the high-affinity site. The decrease is markedly less when the adsorption density of $\mathrm{Cs}^{+}$is at or above the high affinity site capacity, because $\mathrm{Cs}^{+}$adsorption on the low affinity sites shows little temperature dependence. The

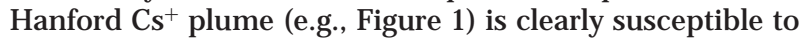
temperature effects because thecombined adsorption density of all $\mathrm{Cs}^{+}$isotopes $\left(8.8 \times 10^{-10}-2.4 \times 10^{-8} \mathrm{~mol} / \mathrm{g}\right)$ is below the total concentration of high affinity sites $\left(\sim 4 \times 10^{-8} \mathrm{~mol} /\right.$ g) (Figure 6). 
This study also showed that $\mathrm{Cs}^{+}$desorption from sediment that had been contaminated for over $30 \mathrm{yr}$ could be well modeled by an equilibrium two-site exchange model corrected by the enthalpy effect up to 60 pore volumes of fluid passage. This volume of leaching solution is orders of magnitudeabovethat expected for the Hanford vadosezone where natural recharge averages approximately $11 \mathrm{~mm} / \mathrm{yr}$ because of a semi-arid climate. The column desorption study was performed at a porewater velocity $(0.2 \mathrm{~cm} / \mathrm{min})$, that was much faster than typically observed in a silty sand aquifer $(<0.1 \mathrm{~cm} / \mathrm{min})$ (18). Therefore, over normal ranges in porewater velocity found in the vadose zone and groundwater, $\mathrm{Cs}^{+}$sorption and desorption in contaminated Hanford sediment can beaccurately described as an equilibrium mass exchange reaction between aqueous and solid phases. The most critical unknown variable is the exchangeable fraction of $\mathrm{Cs}^{+}$, and insufficient measurements have been performed to predict this variable. A kinetic release model, such as that developed in ref 12 , would be needed to predict $\mathrm{Cs}^{+}$migration in this particular plume (e.g., SX-108 at Hanford) if large volumes of water were to pass through the sediment (e.g., $>60$ pore volumes) or if leaching were to occur at rapid rate.

\section{Acknowledgments}

Research was supported by the U.S. Department of Energy (DOE) through the Environmental Management Science Program and the Hanford Science and Technology Program managed by the Groundwater Protection Project. Pacific Northwest National Laboratory is operated for the DOE by Battelle Memorial Institute under Contract DE-AC0676RL01830.

\section{Literature Cited}

(1) Sawhney, B. L. Clays Clay Miner. 1972, 20, 93-100.

(2) Francis, C. W.; Brinkley, F. S. Nature 1976, 260, 511-513.

(3) Zachara, J. M.; Smith, S. C.; Liu, C.; McKinley, J. P.; Serne, R. J.; Gassman, P. L. Geochim. Cosmochim. Acta 2002, 66, 193-211.
(4) Brouwer, E.; Baeyens, B.; Maes, A.; Cremers, A. J. Phys. Chem. 1983, 87, 1213-1219.

(5) Poinssot, C.; Baeyens, B.; Bradbury, M. H. Geochim. Cosmochim. Acta 1999, 63, 3217-3227.

(6) Liu, C.; Zachara, J. M.; Smith, S. C. J. Contam. Hydrol. 2003, submitted.

(7) Eberl, D. D. Clays Clay Miner. 1980, 28, 161-172.

(8) Onodera, Y.; Iwasaki, T.; Ebina, T.; Hayashi, H.; Torii, K.; Chatterjee, A.; Mimura, H. J. Contam. Hydrol. 1998, 35, 131140.

(9) Komarneni, S.; Roy, D. M. Clays Clay Miner. 1980, 28, 142-148.

(10) Brown, D. L.; Haines, R. I.; Owen, D. G.; Stanchell, F. W.; Watson, D. G. In Geochemical Behavior of Disposed Radioactive Waste: Barney, G. S., Navratil, J. D., Schulz, W. W., Eds.; American Chemical Society: Washington, DC, 1984; pp 217-227.

(11) Komarneni, S.; White, W. B. Clays Clay Miner. 1981, 29, 299 308.

(12) Liu, C.; Zachara, J. M. Smith, S. C.; McKinley, J. P.; Ainsworth, C. C. Geochim. Cosmochim. Acta 2003, in press.

(13) Serne, R. . .; Schaef, H.T.; Last, G. V.; Lanigan, D. C.; Lindenmeier, C. W.; Clayton, R. E.; LeGore, V. L.; O'Hara, M. J.; Brown, C. F.; Orr, R. D.; Kutnyakov, I. V.; Wilson, T. C.; Burke, D. B.; Williams, B. A.; Bjornstad, B. N. Geologic and Geochemical Data Collected from VadoseZoneSediments from theSlant Boreholeunder SX108 in the S/SX Waste Management Area and Preliminary Interpretations; Pacific Northwest National Lab: 2001.

(14) Andersson, K.; Torstenfelt, B.; Allard, B. Sorption of radionuclides in geologic systems; 1983.

(15) Lieser, K. H.; Gleitsman, B.; Peschke, S.; Steinkopf, T. Radiochim. Acta 1986, 40, 39-47.

(16) Marley, N. A.; Gaffney, J. S.; Orlandini, K. A.; Cunningham, M. M. Environ. Sci. Technol. 1993, 27, 2456-2461.

(17) McCarty, J. K.; Czerwinski, K. R.; Sanford, W. E.; Jardine, P. M.; Marsh, J. D. J. Contam. Hydrol. 1998, 30, 49-77.

(18) Freeze, R. A.; Cherry, J. A. Groundwater; Prentice-Hall: Englewood Cliffs, NJ, 1979.

Received for review October 8, 2002. Revised manuscript received March 23, 2003. Accepted April 11, 2003.

$\mathrm{ESO26221 \textrm {H }}$ 